\title{
Cytotoxic Effect of Conyza canadensis (L.) Cronquist on Human Lung Cancer Cell Lines
}

\author{
Conyza canadensis (L.) Cronquist'in İnsan Akciğer Kanser Hücre Hatları Üzerine \\ Sitotoksik Aktivitesi
}

Fatma AYAZ', Mehmet SARIMAHMUT², Nurgün KÜÇÜKBOYACl1,*, Engin ULUKAYA ${ }^{3}$

1 Gazi University, Faculty of Pharmacy, Department of Pharmacognosy, 06330 Ankara, TURKEY,

2Uludag University, Faculty of Science and Arts, Department of Biology, 16059 Bursa, TURKEY,

3istinye University, Medical School, Department of Medical Biochemistry, 34010 İstanbul, TURKEY

\begin{abstract}
Asteraceae family plants are receiving great attention because they have potential anticancer activity. Therefore, in this study, the cytotoxic effect of Conyza canadensis (L.) Cronquist (Asteraceae) were tested against human lung adenocarcinoma cell lines (A549 and H1299) for the first time. Cytotoxic effect of the $n$-hexane, chloroform, $n$-butanol and remaining water $\left(\mathrm{R}-\mathrm{H}_{2} \mathrm{O}\right)$ extracts fractioned from the methanol extracts of the aerial parts and roots of $C$. canadensis was investigated using Sulforhodamine B (SRB) assay and percent (\%) viability was measured. The results indicate that the extracts of $C$. canadensis have cytotoxic activities on these cells in a dose-dependent manner. The root extracts exhibited relatively higher cytotoxic effects than the aerial parts of the plant. The most active extract was found to be $n$-hexane extract of the roots with $\mathrm{IC}_{50}$ values 94.73 and $84.85 \mu \mathrm{g} / \mathrm{mL}$ on A549 and $\mathrm{H} 1299$ cell lines, respectively. These results suggest that $C$. canadensis exhibits moderate cytotoxic effect in lung cancer cells. This might be taken into account in its use for therapeutic purposes.
\end{abstract}

Key words: Asteraceae, Conyza canadensis, Cytotoxic activity, Lung cancer, Sulforhodamine B assay

\section{öz}

Asteraceae familyası bitkileri antikanser aktivite potansiyaline sahip olmalarından dolayı büyük ilgi görmektedir. Bundan dolayı, bu çalıșmada, Conyza canadensis (L.) Cronquist'in (Asteraceae) insan akciğer kanser hücre hatlarına karşı (A549 ve H1299) sitotoksik etkisi ilk kez test edilmiștir. C. canadensis' in kökleri ve toprak üstü kısımlarının metanol ekstresinden fraksiyonlanan $n$-hekzan, kloroform, $n$-butanol ve kalan sulu $\left(\mathrm{R}-\mathrm{H}_{2} \mathrm{O}\right)$ ekstrelerinin sitotoksik etkisi Sülforodamin B (SRB) yöntemiyle incelenmiș ve \% canlılık oranı hesaplanmıştır. Sonuçlar $C$. canadensis ekstrelerinin kanser hücreleri üzerinde doza bağlı olarak sitotoksik aktiviteye sahip olduğunu göstermiştir. Kök ekstreleri relatif olarak toprak üstü kısımlarından daha yüksek aktivitede bulunmuştur. En aktif ekstre A549 ve H1299 hücre hatları üzerine IC ${ }_{50}$ değerleri sırasıyla 94.73 ve $84.85 \mu \mathrm{g} / \mathrm{mL}$ olan köklerin $n$-hekzan ekstresi olarak tespit edilmiştir. Bu sonuçlar $C$. canadensis'in akciğer kanseri hücrelerinde orta derecede sitotoksisite gösterdiğini belirtmektedir. Bu durum bitkinin terapötik amaçlar için değerlendirilebileceğini göstermektedir.

Anahtar kelimeler: Asteraceae, Conyza canadensis, Sitotoksik aktivite, Akciğer kanseri, Sülforodamin B testi

\section{INTRODUCTION}

Cancer is a major group of diseaes and is still among the leading of death in the world (1). Natural products are important sources of anticancer lead molecules. Many success plant-derived anticancer drugs such as paclitaxel, docetaxel, vincristin, etoposide, camptothecin, irinotecan are clinically available; however due to the rapid development of resistance to chemotherapeutic drugs and their side effetcs, novel anticancer drugs of natural sources are under an extensive search for cancer therapy $(2,3)$.

The family Asteraceae which contains over 1600 genera and more than 23000 species is the largest family with rich chemical constituents (4). It has a broad medicinal utilization worldwide in which over 300 species of the family are known to have ethnomedicinal uses for cancer related diseases (5). The number of studies related to the cytotoxicity of Asteraceae plants and their secondary metabolites have 
intensively investigated in recent years. In these studies, sesquiterpene lactones and flavonoids have been principally stated to be responsible compounds for the cytotoxic effects (6-10). These compounds induce apoptosis after disrupting cell cycle of cancer cells in vitro and in vivo and also inhibit angiogenesis and metastasis $(11,12)$.

The genus Conyza Less. belongs to the family Asteraceae and consists of about fifty species all over the world. In Turkey, the genus Conyza is represented by three species in the flora of Turkey, namely C. canadensis (L.) Cronquist, C. bonariensis (L.) Cronquist, and C. albida Willd. ex. Sprengel $(13,14)$. C. canadensis (syn. Erigeron canadensis L.), known as "Canadian fleabane" or "horseweed", is native throughout of North America and is also widespread in Europe. It is an annual plant erecting 10 to $180 \mathrm{~cm}$ high, with sparsely hairy stems (15). C. canadensis was reported to be used for its diuretic, antibacterial, anti-inflammatory, tonic, astringent, antihaemorrhagic properties as well as for the treatment of diarrhea and dysentery in folk medicines (16-18). In addition, a decoction of the plant is used anticancer purposes in North America (19).

The phytochemical studies on $C$. canadensis have so far pointed out to presence of terpenes, acetylene derivatives, flavonoids, benzoic acid derivatives, alkaloids, essential oils, sphingolipids, fatty acids and sterols (20-26). Among them, $C_{10}$ acetylenes such as diyn-ene (e.g. E-lachnophyllum methyl ester) and ene-diyn-ene (e.g. matricaria methyl ester isomers), and $\mathrm{C}_{10}$ lactones (e.g. $8 Z$-matricaria- $\boldsymbol{\gamma}$-lactone) are typical constituents of the genus $(20,26)$.

C. canadensis have been demonstrated to exert several biological activities such as cytotoxic, antifungal, antibacterial, antiviral, anti-inflammatory, antioxidant, and antiagregant (26-33). In previous studies, the extracts from $C$. canadensis were reported to have prominent cytotoxic effects on various cancer cell lines (26,34-37). To the best of our knowledge, there is no scientific report available in support of the cytotoxic effect of C. canadensis on A549 and H1299 human lung cancer cells. The aim of the present study was to investigate the possible in vitro cytotoxic effect of the extracts from the aerial parts and roots of $C$. canadensis in human lung adenocarcinoma cell lines (A549 and H1299).

\section{EXPERIMENTAL}

\section{Chemicals}

In the extraction procedure, methanol, $n$-hexane, chloroform and $n$-butanol were of analytical grade and were purchased from Merck Co. (Darmstadt, Germany). Analytical thin layer chromatography (TLC) was performed on precoated Kieselgel $60 \mathrm{~F}_{254}$ plates (Art. 5554, Merck). The plates sprayed with anisaldehyde reagent [76\% methanol (Merck) and 19\% orthophosphoric acid (Riedel-De Haën, Buchs, SG Switzerland), $5 \% p$-anisaldehyde (Merck)], 30\% $\mathrm{H}_{2} \mathrm{SO}_{4}$ (Merck) solution in $\mathrm{MeOH}$ (Merck) and $1 \%$ vanillin- $\mathrm{H}_{2} \mathrm{SO}_{4}$ solution [vanillin
(Boehringer Mannheim, Mannheim, Germany) and $\mathrm{H}_{2} \mathrm{SO}_{4}$ (Merck)].

\section{Plant material}

Conyza canadensis (L.) Cronquist was collected from Balcova, Izmir, Turkey, in the flowering-fruit stage, in November 2013. The plant was identified by Prof. Dr. Mecit Vural from the Department of Botany, Faculty of Science, Gazi University. A voucher specimen (F. Ayaz 29) has been deposited at Herbarium of Gazi University (GAZI), Ankara, Turkey.

\section{Preparation of extracts}

$39.52 \mathrm{~g}$ powdered aerial parts $(\mathrm{CCH})$ and $40.25 \mathrm{~g}$ roots (CCR) of the plant were extracted with $80 \%$ methanol by stirring at $40^{\circ} \mathrm{C}$ for $6 \mathrm{~h}$ three times $(3 \times 300 \mathrm{~mL})$. Following filtration, the combined methanol extracts were evaporated in vacuo at $40^{\circ} \mathrm{C}$ to dryness. The concentrated $\mathrm{MeOH}$ extracts $(100 \mathrm{~mL})$ were further fractionated by successive solvent extractions with $n$-hexane $(3 \times 100 \mathrm{~mL})$, chloroform $(3 \times 100 \mathrm{~mL})$ and $n$-butanol saturated with $\mathrm{H}_{2} \mathrm{O}(3 \times 100 \mathrm{~mL})$ in a separatory funnel. Each extract as well as remaining aqueous phase $\left(\mathrm{R}-\mathrm{H}_{2} \mathrm{O}\right)$ after solvent extractions was evaporated to dryness under reduced pressure to yield " $n$-Hexane extract" $(0.04 \mathrm{~g}$ for $\mathrm{CCH}, 0.29$ $\mathrm{g}$ for CCR), " $\mathrm{CHCl}_{3}$ extract" ( $0.14 \mathrm{~g}$ for $\mathrm{CCH}, 0.30 \mathrm{~g}$ for CCR), " $n$-BuOH extract" (2.63 g for $\mathrm{CCH}, 1.86 \mathrm{~g}$ for CCR) and " $\mathrm{R}-\mathrm{H}_{2} \mathrm{O}$ extract" (1.03 g for $\mathrm{CCH}, 2.83$ for CCR), respectively.

\section{Phytochemical analysis}

$1 \mathrm{mg} / \mathrm{mL}$ of $C$. canadensis extracts were applied to silica gel plates. The $n$-hexane and $\mathrm{CHCl}_{3}$ extracts were developed with the mixture of $n$-hexane:acetone (7:3) as a mobile phase. TLC plates were evaluated under UV light at 254 and $366 \mathrm{~nm}$ for the determination of fluorescent compounds. Anisaldehyde reagent and $30 \% \mathrm{H}_{2} \mathrm{SO}_{4}$ were sprayed to the plates to visualize the separated compounds and then plates were heated for $5 \mathrm{~min}$ at $100^{\circ} \mathrm{C}$. Terpenes were appeared in pink, purple and green coloration with anisaldehyde reagent. In addition, terpenes also showed red coloration under UV $254 \mathrm{~nm}$ sprayed with $30 \% \mathrm{H}_{2} \mathrm{SO}_{4}$ after heating for $5 \mathrm{~min}$ at $100^{\circ} \mathrm{C}$. The $n$-butanol and $\mathrm{R}-\mathrm{H}_{2} \mathrm{O}$ extracts were developed in a mixture of solvent system $\mathrm{CHCl}_{3}: \mathrm{MeOH}: \mathrm{H}_{2} \mathrm{O}$ (61:32:7) and then sprayed with $1 \%$ vanillin- $\mathrm{H}_{2} \mathrm{SO}_{4}$ solution. The plates were heated for $5 \mathrm{~min}$ at $100^{\circ} \mathrm{C}$ before examined under UV light. Flavonoids detected as yellow and orange zones on the plates (38).

\section{Cell culture}

A549 and H1299 human lung adenocarcinoma cells were kindly provided by Prof. Hakan Akça (Pamukkale University, Faculty of Medicine, Denizli, Turkey). A549 and H1299 cells were cultured in RPMI 1640 medium supplemented with penicillin $\mathrm{G}(100 \mathrm{U} / \mathrm{mL})$, streptomycin $(100 \mathrm{mg} / \mathrm{mL}), \mathrm{L}$-glutamine, and $10 \%$ fetal bovine serum at $37^{\circ} \mathrm{C}$ in a humidified atmosphere containing $5 \% \mathrm{CO}_{2}$.

\section{Cytotoxicity assay}

For the Sulforhodamine B (SRB) assay, which is routinely performed by National Cancer Institute $(\mathrm{NCl})$ for in vitro drug screening, $n$-hexane, chloroform, $n$-butanol and remaining 
water extracts were added to 96-well plates to make up a final concentration range of $1.56 \mu \mathrm{g} / \mathrm{mL}$ to $100 \mu \mathrm{g} / \mathrm{mL}$ by serial dilutions (six two-fold dilutions). Then, A549 and H1299 cells were seeded at a density of $5 \times 10^{3}$ cells per well of 96 -well plates. Subsequently, cells were incubated with various concentrations of the aerial parts and roots extracts for $48 \mathrm{~h}$. The assay was terminated by the addition of ice-cold $50 \%(\mathrm{w} / \mathrm{v})$ trichloroacetic acid. SRB $0.4 \%(\mathrm{w} / \mathrm{v})$ in $1 \%(\mathrm{v} / \mathrm{v})$ acetic acid staining was then performed. The bound dye was extracted using $10 \mathrm{mM}$ unbuffered Tris and optical density was measured at $564 \mathrm{~nm}$ with an ELISA plate reader (FLASH Scan S12, Analytik Jena, Germany). Viability of treated cells was calculated in reference to the untreated control cells by using the following formula:

Cell viability $(\%)=[100 \times($ Sample Abs $) /($ Control Abs $)]$.

\section{RESULTS AND DISCUSSION}

The cytotoxic effect of the extracts from the aerial parts and roots of $C$. canadensis on lung cancer cell lines (A549 and H1299) were first investigated by the SRB assay after treating cells with increasing doses of extracts $(1.56 \mu \mathrm{g} / \mathrm{mL}$ $100 \mu \mathrm{g} / \mathrm{mL}$ ) for $48 \mathrm{~h}$. It was found that the extracts inhibited

H1299

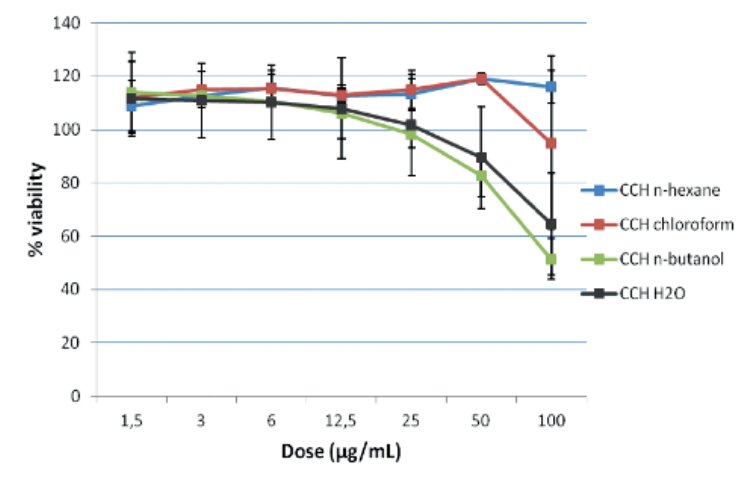

Figure 1a. The cytotoxic effects with different concentrations of the aerial parts extracts of $C$. canadensis on $\mathrm{H} 1299$ cell lines

A549

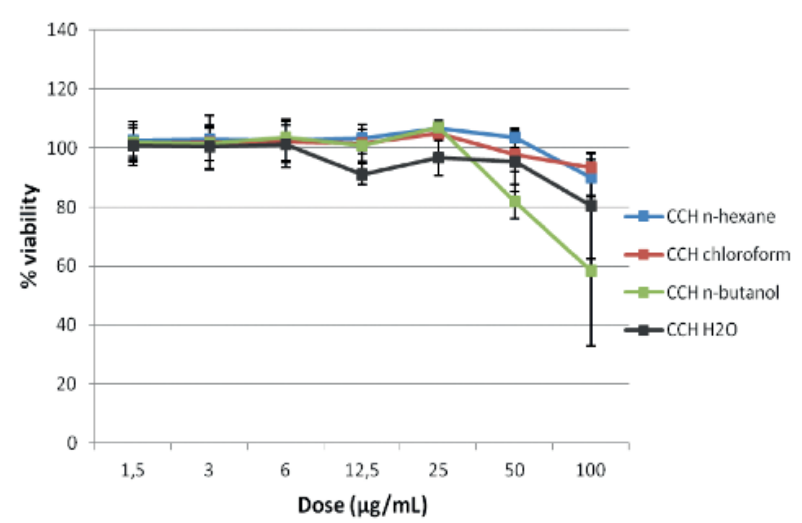

Figure $1 \mathrm{~b}$. The cytotoxic effects with different concentrations of the aerial parts extracts of $C$. canadensis on $A 549$ cell lines growth of cells in a dose-dependent manner and prominently reduced the cell viability at the $100 \mu \mathrm{g} / \mathrm{mL}$. The cytotoxic effects after the treatment with the extracts against human lung adenocarcinoma cell lines were shown in Figures 1a, 1b, $2 \mathrm{a}$ and $2 \mathrm{~b}$.

In order to compare antigrowth effects of various concentrations of the aerial parts and roots extracts of C. canadensis, the root extracts exhibited relatively higher antigrowth effects than the aerial parts extracts. The strongest cytotoxic activity was detected for the $n$-hexane extract of the roots with $I_{50}$ values 94.73 and $84.85 \mu \mathrm{g} /$ $\mathrm{mL}$ on $\mathrm{A} 549$ and $\mathrm{H} 1299$ cell lines, respectively. Overall, the antigrowth effects of the extracts were not dependent on the cell line. Considering the fact that A549 expresses wild type p53 and $\mathrm{H} 1299$ is p53 null, it can be stated that the resulting antigrowth effects of the extracts are p53 independent (39). This may actually be favorable because majority of cancers have mutated $p 53$, thereby these extracts would still be active against even p53-mutated ones.

To the best of our knowledge, this is the first attempt rationalizing the cytotoxic effect of $C$. canadensis on A549 and H1299 human lung cancer cells. Neverthless, a few

\section{H1299}

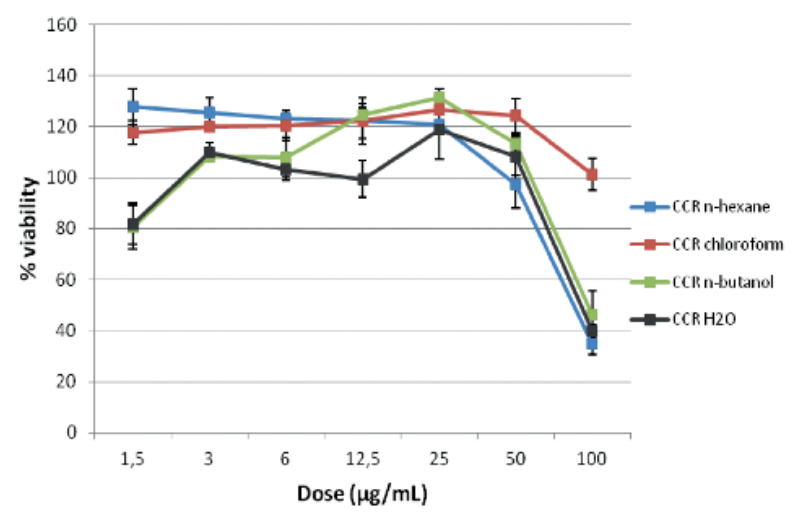

Figure 2a. The cytotoxic effects with different concentrations of the root extracts of $C$. canadensis on $\mathrm{H} 1299$ cell lines

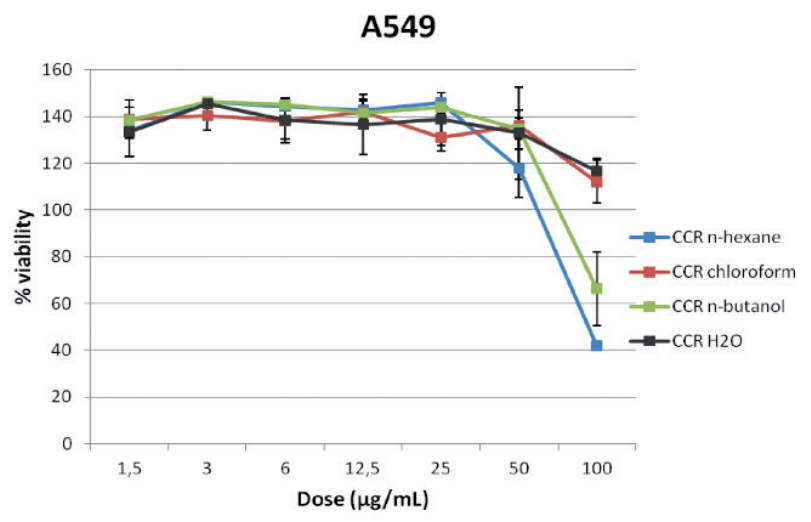

Figure $2 \mathrm{~b}$. The cytotoxic effects with different concentrations of the root extracts of $C$. canadensis on A549 cell lines 
studies demonstrated earlier cytotoxic effect of the extracts of $C$. canadensis of different origin having varying levels of inhibition on various cancer cell lines (26,34-37). For instance; $n$-hexane, chloroform and aqueous $\mathrm{MeOH}$ extracts partitioned from $\mathrm{MeOH}$ extract of the aerial parts, flowers and roots of $C$. canadensis and the $\mathrm{H}_{2} \mathrm{O}$ extracts prepared from the residual plant materials were investigated for their cytotoxic properties on HeLa, MCF-7 and A431 cell lines using the MTT assay. The $n$-hexane phase of the roots exhibited markedly antigrowth effects on the cell lines (62.4-70.1\%) at $10 \mu \mathrm{g} / \mathrm{mL}$, and the $\mathrm{CHCl}_{3}$ phase of the roots demonstrated moderate antiproliferative activity (39.3-47.9\%) at the same concentration (34). According to the bioactivity-guided fractionation of the $n$-hexane and chloroform phases of the methanol extract from the roots of $C$. canadensis, two new unusual $C_{10} \gamma$-dihydropyranone derivatives (conyzapyranone $A$ and conyzapyranone B), as well as $2 \gamma$-lactone acetylene derivatives (e.g. 4E,8Z-matricaria- $\gamma$-lactone), triterpenes, sterols (e.g. spinasterol), a hydroxy fatty acid and a flavonoid were isolated. Among them, conyzapyranone B, 4E,8Zmatricaria- $\boldsymbol{\gamma}$-lactone and spinasterol were found to have remarkable antiproliferative activity against HeLa, MCF-7 and $A 431$ cell lines (26). In other study, cytotoxic activities of petroleum ether, ethyl acetate and methanol extracts of the aerial parts of $C$. canadensis were investigated on Hep-2 using methylene blue assay at 24,48 and 72 h of incubation. At 72 $h$ of incubation, the most active extracts were found to be ethyl acetate and petroleum ether extracts with $\mathrm{IC}_{50}$ values 45 and $50 \mu \mathrm{g} / \mathrm{mL}$, respectively (36). In another study, erigeronol, a new triterpene derivative, was isolated from $C$. canadensis as a potent cytotoxic compound with $\mathrm{IC}_{50}$ value of $7.77 \pm 0.47$ $\mu \mathrm{g} / \mathrm{mL}$ on melanoma B16 cell line by the MTT method (37). In these studies, triterpenes, $C_{10}$ acetylene derivatives and dihydropyranones have mainly found as effective cytotoxic constituents in C. canadensis $(26,37)$. In our study, terpenes and flavonoids were principally detected in the root extracts according to the preliminary phytochemical analysis.

The present investigation represents a preliminary screen for the cytotoxic effect of $C$. canadensis in human lung cancer cell lines. In accordance with the National Cancer Institute Guidelines, extracts with $I_{50}$ values $\langle 20 \mu \mathrm{g} / \mathrm{mL}$ were accepted as active (40). This study resulted in moderate cytotoxic activity compared to the previous studies against the selected cell lines which might be attributed to usage of different cell lines as well as the diverse phytochemical composition in the extracts. The present results are also in accordance with ethnomedicinal uses of the plant reported by Hartwell (Hartwell, 1968).

In conclusion, we provided the first evidence for cytotoxic effects of $C$. canadensis against A549 and H1299 cancer cell lines although it shows the cytotoxic activity at relatively higher doses.

\section{ACKNOWLEDGEMENTS}

The authors would like to thank to Prof. Dr. Mecit Vural from the Department of Botany, Faculty of Science, Gazi University, Ankara, Turkey for the identification of the plant.

\section{REFERENCES}

1. World Health Organization, WHO Library Cataloguing-in-Publication Data World Health Statistics 2010, Who Press, Geneva 27, Switzerland, World Health Organization 2010.

2. Demain $A L$, Vaishnav $P$, Natural products for cancer chemotherapy, Microbial Biotechnol, 5(6), 687-699, 2011.

3. Mondal S, Bandyopadhyay S, Ghosh MK, Mukhopadhyay S, Roy S, Mandal C, Natural products: Promising resources for cancer drug discovery, Anticancer Agents Med Chem 12(1), 49-75, 2012.

4. Jeffrey C, Compositae - Introduction with key to tribes. In: Kadereit JW, Jeffrey C, eds. The Families and Genera of Vascular Plants: VIII, Flowering Plants Eudicots Asterales, Springer-Verlag: Berlin, Germany, 61-86, 2007.

5. Graham JG, Quinn ML, Fabricant DS, Farnsworth NR, Plants used against cancer - An extension of the work of Jonathan Hartwell, J Ethnopharmacol 73, 347-377, 2000.

6. Zheng GQ, Cytotoxic terpenoids and flavonoids from Artemisia annua, Planta Med 60, 54-57, 1994.

7. Woerdenbag HJ, Merfort I, Passreiter CM, Schmidt TJ, Willuhn G, Vanuden W, Pras N, Kampinga HH, Konings AWT, Cytotoxicity of flavonoids and sesquiterpene lactones from Arnica species against the Glc-4 and the Colo-320 cell lines, Planta Med 60, 434-437, 1994.

8. Koukoulitsa E, Skaltsa H, Karioti A, Demetzos C. Dimas K, Bioactive sesquiterpene lactones from Centaurea species and their cytotoxic/ cytostatic activity against human cell lines in vitro, Planta Med 68, 649-652, 2002

9. Modzelewska A, Sur S, Kumar SK, Khan SR, Sesquiterpenes: Natural products that decrease cancer growth, Curr Med Chem Anticancer Agents 5, 477-499, 2005.

10. Pan L, Lantvit DD, Riswan S, Kardono LBS, Chai HB, de Blanco EJC, Farnsworth NR, Soejarto DD, Swanson SM, Kinghorn AD, Bioactivityguided isolation of cytotoxic sesquiterpenes of Rolandra fruticosa, Phytochemistry 71, 635-640, 2010.

11. Zhang S, Won YK, Ong CN, Shen HM, Anti-cancer potential of sesquiterpene lactones: bioactivity and molecular mechanisms, Curr Med Chem Anticancer Agents 5, 239-249, 2005.

12. Patel D, Shukla S, Gupta S, Apigenin and cancer chemoprevention: Progress, potential and promise, Int J Oncol 30, 233-245, 2007.

13. Grierson AJC, Conyza Less. In: Davis PH, ed. Flora of Turkey and the East Aegean Islands, Vol 5, pp 132-133, Edinburgh at the University Press: Edinburgh, 1975.

14. Davis PH, Mill RR, Kit T, Conyza Less. In: Davis PH, Mill RR, Kit T, eds. Flora of Turkey and the East Aegean Islands, Vol 10, pp 161-162, Edinburgh at the University Press: Edinburgh, 1988.

15. Weaver SE, The biology of Canadian weeds Conyza canadensis, Can J Plant Sci 8, 867-875, 2001.

16. Metwally AM, Saleh MRI, Aggag M, Khafagy SM, Phytochemical investigation of Erigeron crispus, Planta Med 23, 281-285, 1973.

17. Li TSC, Chinese and Related North American Herbs: Phytopharmacology and Therapeutic Values, CRC Press: Boca Raton, Florida, 2002. 
18. Gruenwald J, Brendler T, Jaenicke C, Physician's Desk Reference for Herbal Medicines, $3^{\text {rd }}$ ed, Thomson Medical Economics Montvale: NJ, USA, 2004.

19. Hartwell J, Plants used against cancer: A survey, Lloyd 31, 71-170, 1968.

20. Bohlmann F, Jakupovic J, 8-Oxo-alpha-selinene and new scopoletin derivatives from Conyza species, Phytochemistry 18, 1367-1370, 1979.

21. Mukhtar N, Iqbal K, Anis I, Malik A, Sphingolipids from Conyza canadensis. Phytochemistry 61, 1005-1008, 2002.

22. Mukhtar N, Iqbal K, Malik A, Novel sphingolipids from Conyza canadensis, Chem Pharm Bull 50, 1558-1560, 2002.

23. Li X, Pan J, Gao K, $\gamma$-Pyranone derivatives and other constituents from Erigeron annuus, Pharmazie 61, 474-477, 2006.

24. Xie WD, Gao X, Jia ZJ, A new acetylene and a new triterpenoid from Conyza canadensis, Arch Pharm Res 30, 547-551, 2007.

25. Ding X, Su Y, Guo H, Yang F, Mao H, Gao X, Zhu Z, Tu G, Phenypropanoid esters from horseweed (Conyza canadensis) and their inhibitory effects on catecholamine secretion, J Nat Prod 73, 270-274, 2010.

26. Csupor-Löffler B, Hajdú Z, Zupkó I, Molnár J, Forgo P, Vasas A, Kele Z, Hohmann J, Antiproliferative constituents of the roots of Conyza canadensis, Planta Med 77, 1183-1188, 2011.

27. Lenfeld J, Motl O, Trka A, Anti-inflammatory activity of extracts from Conyza canadensis, Pharmazie 41, 268-269, 1986.

28. Olas B, Saluk-Juszczak J, Pawlaczyk I, Nowak P, Kolodziejczyk J, Gancarz R, Wachowicz B, Antioxidant and antiaggregatory effects of an extract from Conyza canadensis on blood platelets in vitro, Platelets 17, 354-360, 2006.

29. Shah NZ, Mir AK, Muhammad N, Azeem S, Antimicrobial and phytotoxic study of Conyza canadensis, Middle-East J Med PI Res 1, 63-67, 2012

30. Shah NZ, Mir AK, Muhammad N, Azeem S, Rauf A, Studies on the chemical constituents and antioxidant profile of Conyza canadensis, Middle-East J Med PI Res 1, 32-35, 2012.
31. Edziri HL, Laurent G, Mahjoub A, Mastour M, Antiviral activity of Conyza canadensis (L.) Cronquist extracts grown in Tunisia, Afr J Biotechnol 10, 9097-9100, 2011.

32. Ni LX, Hao XY, Li SY, Chen SJ, Ren GX, Zhu L, Inhibitory effects of the extracts with different solvents from three compositae plants on cyanobacterium Microcystis aeruginosas, Sci China Chem 54, 11231129, 2011.

33. Shakirullah M, Ahmad H, Shah MR, Ahmad I, Ishaq M, Khan N, Badshah A, Khan I, Antimicrobial activities of conyzolide and conyzoflavone from Conyza canadensis, J Enzym Inhib Med Chem 26, 468-471, 2011.

34. Réthy B, Csupor-Löffler B, Zupkó I, Hajdú Z, Máthé I, Hohmann J, Rédei T, Falkay G, Antiproliferative activity of Hungarian Asteraceae species against human cancer cell lines Part I, Phytother Res 21, 1200-1208, 2007

35. Choi HJ, Wang HY, Kim YN, Heo SJ, Kim NK, Jeong MS, Park YH, Kim $\mathrm{S}$, Composition and cytotoxicity of essential oil extracted by steam distillation from horseweed (Erigeron canadensis L.) in Korea, Han'guk Eungyong Sangmyong Hwahakhoeji 51, 55-59, 2008.

36. Hayet E, Maha M, Samia A, Ali MM, Souhir B, Abderaouf K, Mighri Z, Mahjoub A, Antibacterial, antioxidant and cytotoxic activities of extracts of Conyza canadensis (L.) Cronquist growing in Tunisia, Med Chem Res 18, 447-454, 2009.

37. Yan MM, Li TY, Zhao DQ, Shao S, Bi SN, A new derivative of triterpene with anti-melanoma B16 activity from Conyza canadensis, Chinese Chem Lett 21, 834-837, 2010.

38. Wagner H, Bladt S, Plant Drug Analysis: A Thin Layer Chromatography Atlas, $2^{\text {nd }}$ ed, Springer-Verlag: Berlin, Germany, 2001.

39. Yu J, Yue W, Wu B, Zhang, L, PUMA Sensitizes Lung Cancer Cells to Chemotherapeutic Agents and Irradiation, Clin Cancer Res 12, 29282936, 2006.

40. Suffness MS, Pezzuto MJ, Assays related to cancer drug discovery, In: Dey PM, Harborne JB, eds. Methods in Plant Biochemistry, pp 71133, Academic Press: London, UK, 1991.

Received : 20.05.2016

Accepted : 02.06.2016 